\section{Fatty Alcohol Application to Control Meristematic Regrowth in Bottle Gourd and Interspecific Hybrid Squash Rootstocks Used for Grafting Watermelon}

\author{
Shawna L. Daley and Richard L. Hassell ${ }^{1}$ \\ Department of Plant and Environmental Sciences, Clemson University \\ Coastal Research and Education Center, 2700 Savannah Highway, \\ Charleston, SC 29414
}

Additional index words. cucurbit grafting, sucker control, shoot apical meristem, Citrullus lanatus, Lagenaria sicereria, Cucurbita maxima $\times$ Cucurbita moschata

\begin{abstract}
Application of fatty alcohol compounds to rootstock meristems can control rootstock meristematic regrowth, thus decreasing the cost of producing grafted watermelon transplants by reducing the labor. Eight rates of Fair $85^{\circledR}$ and Off-Shoot $T^{\circledR}$, two commercially available fatty alcohol compounds, were applied to the meristem region of bottle gourd (Lagenaria sicereria cv. Emphasis) and interspecific hybrid squash (Cucurbita maxima $\times$ Cucurbita moschata cv. Carnivor) rootstocks to determine the optimal application rate to control regrowth without damaging the remaining plant parts. A water-only control treatment was also included. Rootstock seedlings were rated for damage and regrowth on Days 1, 7, 14, and 21 after treatment. Damage increased and regrowth decreased with increasing rates of fatty alcohol compound. In addition, a significant compound-by-rate interaction indicated that inert ingredients in the fatty alcohol formulation have an effect on both damage and regrowth. The optimal treatment rate, e.g., providing at least $95 \%$ control of regrowth with less than $10 \%$ damage, was found to be between a $5 \%\left(\right.$ Off-Shoot $\left.T^{\circledR}\right)$ and $6.25 \%\left(\right.$ Fair $\left.85^{\circledR}\right)$ fatty alcohol application. At the optimal treatment rate, no adverse effects to grafting success were observed in the grafting procedure.
\end{abstract}

Grafted watermelon transplants are an important part of worldwide watermelon production because they confer resistance to soilborne diseases such as fusarium wilt (Fusarium oxysporum f. sp. niveum) and Monosporascus root rot (Monosporascus cannonballus) (Beltran et al., 2008; Guan et al., 2012; Louws et al., 2010). Grafting can also control root-knot nematode (Meloidogyne spp.) using wild watermelon (Citrullus lanatus var. citroides) or Cucumis metuliferus as a rootstock (Sigüenza et al., 2005; Thies et al., 2010). In addition to disease resistance, grafting watermelon onto vigorous rootstocks provides various other benefits, including increased yield and fruit quality (Ozlem et al., 2007), increased resistance to abiotic stresses (Savvas et al., 2010), decreased planting densities (Cushman and Huan, 2008), and increased nutritional components (Davis and Perkins-Veazie, 2005). Currently, the United States is one of the few countries worldwide that does not use grafted cucurbit transplants

Received for publication 18 Nov. 2013. Accepted for publication 27 Dec. 2013.

Technical Contribution No. 6209 of the Clemson University Experiment Station.

${ }^{1}$ To whom reprint requests should be addressed; e-mail rhassel@clemson.edu. meristem removal with a blade during grafting. This method often removes the meristem only partially, and meristem regeneration occurs. The extent of meristem regeneration varies widely and is dependent on the method used, timing of grafting, and the experience of the individual doing the grafting.

Rootstock meristem regrowth also contributes greatly to the cost associated with grafted watermelon transplant production (Choi et al., 2002; Memmott and Hassell, 2010) because it decreases graft success and requires additional labor to control. If the regrowth is not removed manually during production, it will outcompete the watermelon plants (the scion) for light, space, and nutrients, preventing effective healing. In the field, unremoved regrowth can also affect yields by competing with the scion. Even if the regrowth is removed at the transplant stage, additional labor is required to scout and remove regrowth in the field. The labor required for manual regrowth control makes grafted transplants economically impractical for commercial production in the United States. Because grafted transplant production is not currently taking place in the United States, it is unclear what the specific production costs would be. Regardless, a labor-free method of eliminating meristematic regrowth should significantly reduce the overall cost of grafted watermelon transplant production and might help to increase the adoption of grafted cucurbit transplants in the United States.

Chemical inhibition of the meristem region of rootstocks would not only decrease the labor required for grafted transplant maintenance, but would address the variance in regrowth based on grafter skill, timing, and method. However, acceptable removal of the meristem without damaging the rootstock cotyledons has been a challenge. Preserving the quality of the cotyledons is essential, because cucurbit seedlings rely heavily on at least one cotyledon to supply energy for growth and establishment (Bisognin et al., 2005). A chemical treatment would be acceptable for use only if it could destroy the meristem without damaging the cotyledons, which would provide the energy required for rootstock health and graft healing.

Previous studies (Choi et al., 2002) have examined silver nitrate and hydrogen peroxide applications to the meristem region of cucurbit rootstocks, but the application resulted in unacceptably low rootstock survival. Other preliminary research of chemicals including maleic hydrazide, oryzalin, sulfuric acid, and fatty alcohols indicated that only the fatty alcohol successfully destroys the rootstock meristem without damaging the rootstock cotyledons (Hassell, unpublished data). This promising method of regrowth control (US Patent 8,629,330) involves applying a dilute $\mathrm{C}_{6}, \mathrm{C}_{8}, \mathrm{C}_{10}, \mathrm{C}_{12}$ fatty alcohol solution to the meristem area of a rootstock seedling, where it destroys only the rapidly dividing meristem tissue (Steffens et al., 1967) to prevent regrowth while the rootstock seedling remains viable for grafting. 
Commercially available fatty alcohol products are used on tobacco to control axillary meristem growth (suckers) after topping. The compound acts by disrupting the cell's plasma membrane, causing plasmolysis of the cells and desiccation of the tissue (Wheeler et al., 1991). Although the mode of action on tobacco is understood, the specifics of fatty alcohol applications on cucurbit rootstock tissues have not been characterized. The first objective of this experiment was to determine the optimal application rate of commercially available fatty alcohol compounds that would control rootstock regrowth without damaging the rootstock cotyledons and, thus, their potential for grafting. The second objective was to determine whether the fatty alcohol treatment affected the graft success of the rootstocks.

\section{Materials and Methods}

Plant material. Seeds of two rootstocks commonly used in Asia and Europe, bottle gourd (Lagenaria sicereria cv. Emphasis) (Syngenta Seeds, Boise, ID) and interspecific hybrid squash (Cucurbita maxima $\times$ Cucurbita moschata cv. Carnivor) (Syngenta Seeds), were sown in 72-cell, TLC polyform plug flats (cell depth: $5.72 \mathrm{~cm}$, top cell diameter: $3.96 \mathrm{~cm}$, bottom cell diameter: $2.54 \mathrm{~cm}$ ) (TLC Polyform Inc., Minneapolis, $\mathrm{MN})$ using a nutrient-free, soilless mix $(75 \%$ sphagnum peat, $25 \%$ perlite) (Sun Gro Horticulture, Agawam, MA). Seeds were sown on four planting dates, once each week of Aug. 2012, following standard greenhouse production practices (Rutledge, 2009). Seedlings were grown in a standard, double-layer polyethylene greenhouse covered with $6 \mathrm{~mm}$ Klerk's K50 clear plastic (Klerks Hyplast, Inc., Chester, SC). The greenhouse contained a gas heating system to supply heat and exhaust fans to remove heat. Minimum temperatures were set at $15^{\circ} \mathrm{C}$ and the exhaust fans were set to power on when greenhouse temperatures reached $21{ }^{\circ} \mathrm{C}$.

Experimental design and data collection. A split-split plot design was used with the four planting dates as the whole plot factor, compounds applied to half-trays (compound type being the subplot factor), and rates randomized within compound (rates being the sub-subplot factor). Three trays total were used to complete each replication. Each planting date consisted of three replications of 18 individual plants per compound type and rate treatment combination, resulting in a total of 54 plants (observations) per planting date.

Seedling treatment. Two commercially available, concentrated fatty alcohol stock solutions, Fair $85^{\circledR}$ (Fair Products, Inc., Cary, NC) and Off-Shoot $\mathrm{T}^{\circledR}$ (Chemtura Corporation, Lawrenceville, GA), were used in the experiment. Both products contain identical active ingredients $\left(\mathrm{C}_{6} 0.5 \%\right.$, $\mathrm{C}_{8} 42 \%, \mathrm{C}_{10} 56 \%$, and $\mathrm{C}_{12} 1.5 \%$ ) according to the labels. Emulsions were prepared by diluting fatty alcohol in distilled water according to the dilutions presented in Table 1. Rates were based on a $20-\mathrm{mL}$ total volume.
Fatty alcohol treatment began when rootstock seedling cotyledons were completely unfolded and the first true leaf was visible (6 to $8 \mathrm{~d}$ after seeding for bottle gourd and 5 to $7 \mathrm{~d}$ after seeding for the interspecific hybrid). This is the standard rootstock age for grafting (Hassell et al., 2008). Twelve h before treatment, trays of plants were removed from the greenhouse and transferred to a climatecontrolled room to acclimatize seedlings to a standard environment. Temperatures were maintained at a constant $23{ }^{\circ} \mathrm{C}$, and relative humidity was maintained at a range of $50 \%$ to $70 \%$. Single-channel pipettes (VWR International LLC, Radnor, PA) were used to apply $20 \mu \mathrm{L}$ of the emulsion to the meristematic region between the cotyledons. In previous experiments, this volume was found to be the amount that covered the meristematic region of the rootstock without the compound overflowing the area and dripping down the hypocotyl. Seedlings remained in the controlled environment $5 \mathrm{~h}$ after treatment, 2.5 times greater than the 2-h timeframe reported by Wheeler et al. (1991) to be required for the fatty alcohol to penetrate leaf tissue.

Because at least one cotyledon is required for grafting success (Bisognin et al., 2005; Memmott, 2010), it was necessary to determine the effect of the fatty alcohol application on cotyledon damage as well as on regrowth control to ensure rootstock quality for grafting. For cotyledon damage, a rating of 0 was assigned to seedlings with no visible damage (Fig. 1A), whereas seedlings with damaged cotyledons were assigned a rating of 1 (Fig. 1C). For regrowth response, rootstock seedlings with no meristematic regrowth were assigned a regrowth rating of 0 (Fig. 1A), and a rating of 1 was assigned to seedlings with visible meristematic regrowth (Fig. 1B).

Preliminary research revealed that some cotyledons recover from damage incurred by the fatty alcohol and are able to be successfully grafted (Hassell, unpublished data). The rootstock regrowth also occurs over varied amounts of time. To determine the rating day that would most accurately reflect true damage and regrowth after fatty alcohol application, a series of ratings were conducted on Days 1, 7,14 , and 21 after fatty alcohol application.

Grafting experiment. The same rootstock material as described previously was used in the grafting experiment. 'Tri-X 313' (Citrullus lanatus var. lanatus) (Syngenta Seeds) was used as the scion. Scion seeds were sown according to guidelines outlined by Hassell and Schultheis (2002). The experiment was a randomized complete block design with three replications and 12 grafted plants per treatment and was repeated twice on 26 and 28 Aug. 2013. Three different treatments were applied: $6.25 \%$ Off-Shoot $\mathrm{T}^{\circledR}, 6.25 \%$ Fair $85^{\circledR}$, and a water control. Fatty alcohol treatments were chosen based on the results of the previously described rate trial experiment. One day after fatty alcohol treatment, seedlings were grafted using the one-cotyledon grafting method, according to the procedure described by Hassell et al. (2008). Graft success was recorded as a percentage of total grafts attempted.

Data analysis. Damage and regrowth data were separated by rootstock type and analyzed separately with an approximate generalized linear mixed model. The model was a complete factorial model of all combinations and interactions between and among the following fixed effects: planting date, compound, rate, and day of evaluation. Random effects included replication and the interactions among replications and the three fixed factors. Planting date was nested within the factors. In both responses, means were multiplied by 100 and are presented as a percent incidence.

The main effect of day of evaluation appeared to reach an asymptote; thus, a series

Table 1. Dilutions used to create fatty alcohol emulsions $^{\mathrm{z}}$ with Fair $85^{\circledR}$ and Off-Shoot $\mathrm{T}^{\circledR}$.

\begin{tabular}{lccc}
\hline $\begin{array}{l}\text { Water } \\
\text { added } \\
(\mathrm{mL})\end{array}$ & $\begin{array}{c}\text { Compound } \\
\text { added }(\mathrm{mL})\end{array}$ & $\begin{array}{c}\text { Final } \\
\text { volume } \\
(\mathrm{mL})\end{array}$ & $\begin{array}{c}\text { Final } \\
\text { emulsion } \\
\text { percent }\end{array}$ \\
\hline 20.00 & 0.00 & 20.00 & 0.00 \\
19.25 & 0.75 & 20.00 & 3.75 \\
19.00 & 1.00 & 20.00 & 5.00 \\
18.75 & 1.25 & 20.00 & 6.25 \\
18.50 & 1.50 & 20.00 & 7.50 \\
18.25 & 1.75 & 20.00 & 8.75 \\
18.00 & 2.00 & 20.00 & 10.00 \\
17.50 & 2.50 & 20.00 & 12.50 \\
17.00 & 3.00 & 20.00 & 15.00 \\
\hline
\end{tabular}

${ }^{\mathrm{z} E m u l s i o n s}$ were created by measuring desired volume of fatty alcohol compound and bringing to $20 \mathrm{~mL}$ final volume with $\mathrm{diH}_{2} \mathrm{O}$

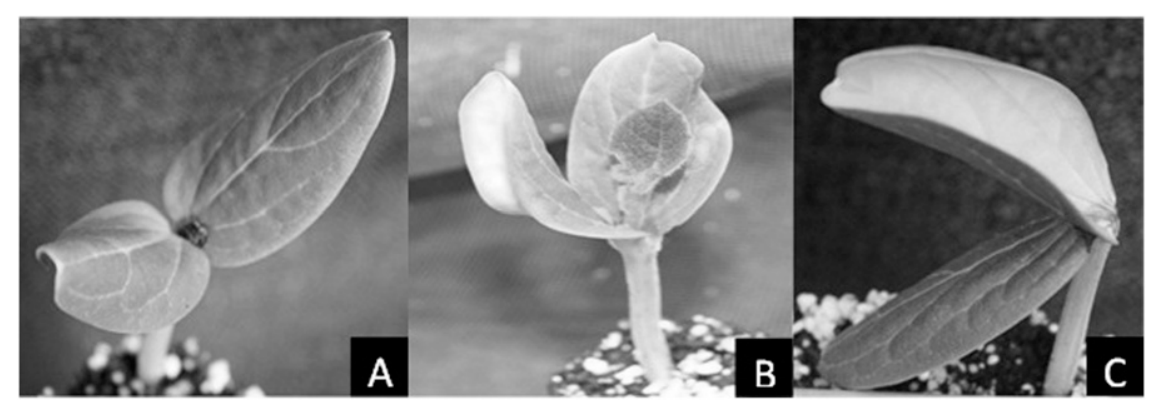

Fig. 1. Rating system for treated seedlings. (A) Treated seedlings with no damage or regrowth were given a rating of 0 in both categories. (B) Treated seedlings with regrowth and no damage were given a rating of 0 for damage and 1 for regrowth. (C) Treated seedlings exhibiting damaged cotyledons were given a rating of 1 for damage and 0 for regrowth. 
of contrasts were used to determine at which day the damage and regrowth responses became constant. Day 14 was used for the final linear mixed model analysis, excluding the data from Days 1, 7, and 21. Effects used in this model included all of these factors with the exception of any factor including day. Multiple means comparisons were performed using Fisher's protected least significant difference test with a $P$ value $\leq 0.05$ considered significant throughout. The choice of Fisher's protected least significant difference test was to reduce the overall probability of Type II errors.

All calculations were performed using the fit model platform of JMP Pro $10^{\circledR}$ Software (SAS Institute Inc., 1989-2010). The reason for a generalized linear mixed model was that both damage and regrowth were binomial random variables. The reason it was an approximate generalized linear mixed model was that the complex nature of the statistical design, including random effects, led to some approximations (using general linear mixed models) to overcome some convergence and estimation issues.

Graft success data were also analyzed with a linear mixed model using the fit model platform of JMP Pro $10^{\circledR}$ Software
(SAS Institute Inc., 1989-2010). Similar to the damage and regrowth data, means are presented as percent incidence. The model for grafting success was a complete factorial model including all combinations and interactions between and among the following fixed effects: planting date, compound, and treatment. Random effects included replication and the interactions among replication and the three fixed factors with planting date nested within the remaining factors.

\section{Results}

Damage response. A significant compoundby-rate interaction existed for damage incidence in both 'Emphasis' and 'Carnivor' $(P<0.0001)$, indicating that the two compounds reacted differently as their concentrations increased (Tables 2 and 3). There were no significant differences in damage incidence in 'Emphasis' seedlings treated with $0 \%, 3.75 \%$, and $5 \%$ of either Fair $85^{\circledR}$ or with $0 \%$ and $3.75 \%$ of Off-Shoot $\mathrm{T}^{\circledR}$ (Table 2). 'Emphasis' rootstock damage incidence increased significantly between $6.25 \%$ and $7.5 \%$ Fair $85^{\circledR}$ and the damage incidences at $10 \%, 12.50 \%$, and $15 \%$ Fair $85^{\circledR}$ were not significantly different

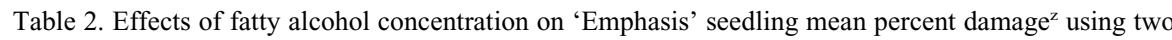
$\left(\mathrm{C}_{6} 0.5 \%, \mathrm{C}_{8} 42 \%, \mathrm{C}_{10} 56 \%, \mathrm{C}_{12} 1.5 \%\right)$ fatty alcohol compounds pooled over three consecutive experiments.

\begin{tabular}{|c|c|c|c|c|}
\hline \multirow{2}{*}{$\begin{array}{l}\text { Fatty alcohol } \\
\text { concn }(\%)\end{array}$} & \multicolumn{2}{|c|}{ 'Emphasis' damage } & \multicolumn{2}{|c|}{ 'Carnivor' damage } \\
\hline & $\overline{\text { Fair } 85^{\circledR \mathrm{y}}(\%)}$ & Off-Shoot $\mathrm{T}^{\circledR \times}(\%)$ & Fair $85^{\circledR}(\%)$ & Off-Shoot $\mathrm{T}^{\circledR}(\%)$ \\
\hline 0.00 & $0.0 \mathrm{~g}^{\mathrm{w}}$ & $0.0 \mathrm{~g}$ & $0.0 \mathrm{~g}$ & $0.0 \mathrm{~g}$ \\
\hline 3.75 & $0.0 \mathrm{~g}$ & $3.1 \mathrm{fg}$ & $0.0 \mathrm{~g}$ & $1.4 \mathrm{~g}$ \\
\hline 5.00 & $9.8 \mathrm{efg}$ & $13.1 \mathrm{ef}$ & $4.9 \mathrm{fg}$ & $8.7 \mathrm{efg}$ \\
\hline 6.25 & $17.2 \mathrm{e}$ & $43.2 \mathrm{~cd}$ & $5.4 \mathrm{fg}$ & $19.0 \mathrm{cde}$ \\
\hline 7.50 & $33.3 \mathrm{~d}$ & $49.3 \mathrm{c}$ & $13.6 \mathrm{def}$ & $25.8 \mathrm{c}$ \\
\hline 8.75 & $34.4 \mathrm{~d}$ & $78.3 \mathrm{~b}$ & $17.3 \mathrm{cde}$ & $43.6 \mathrm{~b}$ \\
\hline 10.00 & $78.4 \mathrm{~b}$ & $91.8 \mathrm{a}$ & $23.7 \mathrm{~cd}$ & $49.3 \mathrm{~b}$ \\
\hline 12.50 & $84.8 \mathrm{ab}$ & $76.6 \mathrm{~b}$ & $48.9 \mathrm{~b}$ & $51.2 \mathrm{~b}$ \\
\hline 15.00 & $92.3 \mathrm{ab}$ & $94.2 \mathrm{a}$ & $69.1 \mathrm{a}$ & $55.1 \mathrm{~b}$ \\
\hline
\end{tabular}

${ }^{2}$ Eighteen seedlings per replication.

'Fair Products, Inc., Cary, NC.

${ }^{\mathrm{x}}$ Chemtura Corporation, Middlebury, CT.

wValues within the two rootstock columns (across compound type) that are not followed by the same letter are significantly different according to Fisher's protected least significant difference test at $P \leq 0.05$.

Table 3. Effects of fatty alcohol concentration on rootstock seedling mean percent regrowth ${ }^{\mathrm{z}}$ using two $\left(\mathrm{C}_{6} 0.5 \%, \mathrm{C}_{8} 42 \%, \mathrm{C}_{10} 56 \%, \mathrm{C}_{12} 1.5 \%\right)$ fatty alcohol compounds pooled over three consecutive experiments.

\begin{tabular}{|c|c|c|c|c|}
\hline \multirow{2}{*}{$\begin{array}{l}\text { Fatty alcohol } \\
\text { concn }(\%)\end{array}$} & \multicolumn{2}{|c|}{ 'Emphasis' regrowth } & \multicolumn{2}{|c|}{ 'Carnivor' regrowth } \\
\hline & Fair $85^{\circledR \mathrm{y}}(\%)$ & ${\text { Off-Shoot } T^{\circledR x}(\%)}$ & $\overline{\text { Fair } 85^{\circledast}(\%)}$ & Off-Shoot $\mathrm{T}^{\circledR}(\%)$ \\
\hline 0.00 & $100.0 \mathrm{a}^{\mathrm{w}}$ & $100.0 \mathrm{a}$ & $100.0 \mathrm{a}$ & $100.0 \mathrm{a}$ \\
\hline 3.75 & $32.7 \mathrm{~b}$ & $14.9 \mathrm{c}$ & $47.1 \mathrm{~b}$ & $35.9 \mathrm{c}$ \\
\hline 5.00 & $16.2 \mathrm{c}$ & $7.7 \mathrm{~d}$ & $26.6 \mathrm{~d}$ & $8.1 \mathrm{e}$ \\
\hline 6.25 & $2.0 \mathrm{de}$ & $2.1 \mathrm{~d}$ & $6.8 \mathrm{e}$ & $0.7 \mathrm{e}$ \\
\hline 7.50 & $1.3 \mathrm{de}$ & $0.0 \mathrm{e}$ & $1.4 \mathrm{e}$ & $0.0 \mathrm{e}$ \\
\hline 8.75 & $0.0 \mathrm{e}$ & $0.0 \mathrm{e}$ & $1.4 \mathrm{e}$ & $0.0 \mathrm{e}$ \\
\hline 10.00 & $0.0 \mathrm{e}$ & $0.0 \mathrm{e}$ & $0.7 \mathrm{e}$ & $0.0 \mathrm{e}$ \\
\hline 12.50 & $0.0 \mathrm{e}$ & $0.0 \mathrm{e}$ & $0.0 \mathrm{e}$ & $0.1 \mathrm{e}$ \\
\hline 15.00 & $0.0 \mathrm{e}$ & $0.0 \mathrm{e}$ & $0.0 \mathrm{e}$ & $0.0 \mathrm{e}$ \\
\hline
\end{tabular}

${ }^{2}$ Eighteen seedlings per replication.

${ }^{\mathrm{y}}$ Fair Products, Inc., Cary, NC.

${ }^{\mathrm{x}}$ Chemtura Corporation Middlebury, CT.

${ }^{w}$ Values within the two rootstock columns (across compound type) that are not followed by the same letter are significantly different according to Fisher's protected least significant difference test at $P \leq 0.05$.

(Table 2). Damage incidence increased significantly between $5 \%$ and $6.25 \%$ Off-Shoot $\mathrm{T}^{\circledR}$ as well as among $7.5 \%, 8.75 \%$, and $10 \%$ Off-Shoot $\mathrm{T}^{\circledR}$. Damage incidence at $12.5 \%$ OffShoot $\mathrm{T}^{\circledR}$ decreased significantly, but damage at $15.00 \%$ was not statistically significant from damage incidence at $10 \%$ Off-Shoot $\mathrm{T}^{\circledR}$ (Table 2).

Damage incidence on 'Carnivor' seedlings also increased with increasing concentrations of fatty alcohol. Seedlings treated with $0 \%, 3.75 \%, 5 \%$, and $6.25 \%$ Fair $85^{\circledR}$ had the lowest amount of damage with no significant differences; however, damage significantly increased from $5.4 \%$ to $13.6 \%$ as rates increased from $6.25 \%$ to $7.50 \%$, respectively, of Fair $85^{\circledR}$ (Table 2). There was no significant increase in damage between $7.50 \%$ and $8.75 \%$, but a significant increase from $23.7 \%$ incidence at $10.00 \%$ to $48.9 \%$ incidence at $12.50 \%$ Fair $85^{\circledR}$ (Table 2). Damage was highest at $15 \%$ Fair $85^{\circledR}$ with $69.1 \%$ incidence (Table 2). Similarly, the Off-Shoot $\mathrm{T}^{\circledR}$ treatment showed no significant differences between rates of $0 \%, 3.75 \%$, and $5 \%$ (Table 2). Damage increased significantly in seedlings treated with $8.75 \%$ Off-Shoot $\mathrm{T}^{\circledR}$ and increased, but not significantly, at the four greatest rates of Off-Shoot $\mathrm{T}^{\circledR}$ (Table 2).

Regrowth response. The compound-byrate interaction was significant in both 'Emphasis' $(P=0.0019)$ and 'Carnivor' $(P=$ $0.0089)$, indicating that regrowth is unequally controlled by the two fatty alcohol compounds (Table 3). 'Emphasis' control seedlings (treated with water) exhibited $100 \%$ regrowth, and seedlings treated with $3.75 \%$ Fair $85^{\circledR}$ resulted in $32.7 \%$ regrowth. Regeneration continued to decrease significantly at both $5 \%$ Fair $85^{\circledR}$ (16.2\% regrowth) and $6.25 \%$ Fair $85^{\circledR}$ ( $2 \%$ regrowth). There was no further significant reduction in regrowth at rates above $6.25 \%$ Fair $85^{\circledR}$ (Table 3). At $3.75 \%$ Off-Shoot $\mathrm{T}^{\circledR}$ treatments, regrowth was significantly reduced to $14.9 \%$. Regrowth again significantly decreased to $7.7 \%$ at $5 \%$ Off-Shoot $\mathrm{T}^{\circledR}$. Regrowth incidence at $6.25 \%$ Off-Shoot $\mathrm{T}^{\circledR}$ caused a decrease to $2.1 \%$ regrowth, which was not significant. However, regrowth at all treatment rates above $7.5 \%$ Off-Shoot $\mathrm{T}^{\circledR}$ were significantly lower than those at $6.25 \%$ Off-Shoot $\mathrm{T}^{\circledR}$ (Table 3). In 'Carnivor' seedlings treated with Fair $85^{\circledR}$, regrowth decreased significantly from the $0 \%$ control ( $100 \%$ regrowth) to $47.1 \%$ regrowth at the rate of $3.75 \%$ Fair $85^{\circledR}$. Regrowth also decreased significantly between $5 \%$ and $6.25 \%$ Fair $85^{\circledR}(26.6 \%$ and $6.8 \%$, respectively) (Table 3). There was no significant decrease in regrowth at rates above $6.25 \%$ (Table 3). Regrowth was problematic when Fair $85^{\circledR}$ was applied at $3.75 \%$ to $5 \%$ (greater than $20 \%$ ), whereas regrowth incidence was less than $10 \%$ at rates above $6.25 \%$ Fair $85^{\circledR}$. In Off-Shoot $\mathrm{T}^{\circledR}$ application rates lower than $6.25 \%$, regrowth was unacceptably high and decreased to less than $1 \%$ incidence above rates of 5\% Off-Shoot $\mathrm{T}^{\circledR}$ (Table 3).

Grafting experiment. There was no significant effect of fatty alcohol treatment $(P=$ 
Table 4. Effect of fatty alcohol treatment ${ }^{2}$ on grafting success of two rootstocks pooled over two consecutive experiments.

\begin{tabular}{lcc}
\hline & \multicolumn{2}{c}{ Grafting success $^{\mathrm{y}}$} \\
\cline { 2 - 3 } Rootstock treatment & 'Carnivor' & 'Emphasis' \\
\hline Fair 85 ${ }^{\circledR \mathrm{x}}$ & $79.2 \mathrm{a}^{\mathrm{v}}$ & $81.9 \mathrm{a}$ \\
Off-Shoot T ${ }^{\circledR \mathrm{w}}$ & $80.6 \mathrm{a}$ & $80.6 \mathrm{a}$ \\
Water & $70.8 \mathrm{a}$ & $75.0 \mathrm{a}$ \\
\hline
\end{tabular}

${ }^{z}$ Rootstocks treated with $6.25 \%$ fatty alcohol emulsion.

${ }^{y}$ Graft success recorded 1 week after removal from healing chamber.

${ }^{x}$ Fair Products, Inc., Cary, NC.

${ }^{w}$ Chemtura Corporation, Middlebury, CT.

"Values within the same column not followed by the same letter are significantly different according to Fisher's least significant difference test at $P \leq$ 0.05 .

0.3608) on graft success. In both 'Carnivor' and 'Emphasis' rootstocks, grafting success was greater in the fatty alcohol-treated rootstocks than the water-treated control; however, the difference was not statistically significant (Table 4). There was also no significant effect of rootstock $(P=0.4199)$. 'Carnivor' rootstocks treated with Fair $85^{\circledR}$ resulted in $79.2 \%$ success, and those treated with Off-Shoot $\mathrm{T}^{\circledR}$ resulted in $80.6 \%$ success (Table 4 ). The water-treated control rootstocks resulted in grafting success of 70.8\%. 'Emphasis' rootstocks treated with Fair $85^{\circledR}$ and Off-Shoot $\mathrm{T}^{\circledR}$ fatty alcohol compounds resulted in $81.94 \%$ and $80.56 \%$, respectively, whereas the control rootstocks resulted in $75 \%$ grafting success (Table 4).

\section{Discussion}

The significance of the compound-by-rate interactions was surprising, because the labels of both Fair $85^{\circledR}$ and Off-Shoot $\mathrm{T}^{\circledR}$ indicate identical amounts $(85 \%)$ of active $\left(\mathrm{C}_{6} 0.5 \%, \mathrm{C}_{8} 42 \%, \mathrm{C}_{10} 56 \%\right.$, and $\left.\mathrm{C}_{12} 1.5 \%\right)$ and inert ingredients (15\%). Although the amount and type of active ingredient in each compound was the same, the alcohol sources may have differed, and this difference could be the source of the observed interaction. On communication with a company representative, we learned that alcohol purity (based on the original alcohol source) is a determining factor in the depth and uniformity of fatty alcohol tissue penetration and resulting chemical burn (Frank Grainger, Fair Products, Inc., personal communication). Steffens and Cathey (1969) reported similar variability in tissue penetration and chemical burn resulting from using surfactants of different hydrophilicities. Because sources of fatty alcohols vary in availability (Frank Grainger, Fair Products, Inc., personal communication), variations in product purity and quality within and between commercially available compounds is highly probable. Thus, it would be essential in commercial applications of this technique to understand the fatty alcohol type and source as well as the resulting effect on rootstocks. Further studies on these aspects would be required to determine these factors.
The general trend of increased damage and decreased regrowth as fatty alcohol concentrations increase was expected, because fatty alcohols are used in the tobacco industry to prevent regrowth of axillary meristems in topped tobacco. In the bottle gourd and interspecific hybrid squash rootstocks, Fair $85^{\circledR}$ and Off-Shoot $\mathrm{T}^{\circledR}$ fatty alcohol solutions at concentrations above $6.25 \%$ eliminated rootstock regrowth in at least $93 \%$ of all seedlings tested; however, the resulting damage incurred by the rootstocks at concentrations above $6.25 \%$ was unacceptably high, especially when Off-Shoot $\mathrm{T}^{\circledR}$ was applied. Choi et al. (2002) reported rootstock similar survival rates of $80 \%$ and $73 \%$ using rootstock applications of $58.8 \mathrm{~mm}$ silver nitrate and $5.48 \mathrm{M}$ hydrogen peroxide, respectively. These data agree with our findings, indicating that complete chemical control of rootstock regrowth requires a level of acceptable damage to the rootstock.

The two rootstocks responded differently to the fatty alcohol treatments. Although damage incidence in both rootstocks followed the same increasing trend, 'Emphasis' rootstocks exhibited higher incidences of damage than 'Carnivor'. As would be expected, regrowth incidence was lower in 'Emphasis' rootstocks as well. This may be the result of physiological differences between the two species. Steffens and Cathey (1969) reported that the extent of fatty acid kill of plant tissue depends on many physiological factors such as leaf type, degree of succulence, and ease of wetting. 'Carnivor' cotyledons are thicker, less succulent, and more pubescent than 'Emphasis' cotyledons. The physiological differences in the rootstock could explain the higher incidence of damage and greater regrowth control observed in 'Emphasis' rootstocks.

The results of the grafting experiment indicate that fatty alcohol applications do not affect rootstocks' ability to be grafted and may have the potential to increase grafting success by eliminating the rootstock meristem. Because the fatty alcohol compounds damage only rapidly dividing tissue (Steffens et al., 1967), only the dividing meristem tissue is damaged by the treatment, and the remaining tissue is still able to produce callus tissue to heal the graft. Although the slight increase in grafting success was statistically insignificant, the increase we observed may be the result of the lack of competition from the rootstock meristem tissue. Because treated rootstocks do not contain active meristems, the rootstock may more readily accept the scion and more easily heal the graft. Because treated rootstocks are not supplying energy to a growing meristem, there may have been slightly more energy available to heal the graft, resulting in a faster healing process.

Fatty alcohol applications can successfully control rootstock meristem growth and by decreasing the labor required would alleviate the high cost of grafted transplant production. Based on our findings, we conclude that a fatty alcohol concentration of $5 \%$ using Off-Shoot $\mathrm{T}^{\circledR}$ and $6.25 \%$ using Fair $85^{\circledR}$ will achieve at least $95 \%$ control of meristematic regrowth with no more than $10 \%$ damage to rootstocks.

\section{Literature Cited}

Beltran, R., A. Vicent, J. Garcia-Jimenez, and J. Armengol. 2008. Comparative epidemiology of monosporascus root rot and vine decline in muskmelon, watermelon, and grafted watermelon crops. Plant Dis. 92:158-163.

Bisognin, D.A., L. Velasquez, and I. Widders. 2005. Cucumber seedling dependence on cotyledonary leaves for early growth. Pesq. Agropec. Bras. Brasilia. 40(6):531-539.

Choi, D.C., S.W. Kwon, B.R. Ko, and J.S. Choi 2002. Using chemical controls to inhibited axillary buds of Lagernaria as rootstock for grafted watermelon (Citrullus lanatus). Acta Hort. 588:43-48.

Cushman, K.E. and J. Huan. 2008. Performance of four triploid watermelon cultivars grafted onto five rootstock genotypes: Yield and fruit quality under commercial growing conditions. Acta Hort. 782:335-342.

Davis, A.R. and P. Perkins-Veazie. 2005. Rootstock effects on plant vigor and watermelon fruit quality. Cucurbit Genet. Coop. Rpt 29:3942.

Davis, A.R., P. Perkins-Veazie, Y. Sakata, S. LopezGalarza, J.V. Marot, S. Lee, Y. Huh, Z. Sun, A. Miguel, S.R. King, R. Cohen, and J. Lee. 2008. Cucurbit grafting. Crit. Rev. Plant Sci. 27:50-74.

Edelstein, M. 2004. Grafting vegetable-crop plants: Pros and cons. Acta Hort. 659:235-238.

Guan, W., X. Zhao, R. Hassell, and J. Thies. 2012. Defense mechanisms involved in disease resistance of grafted vegetables. HortScience 47:164-170.

Hassell, R.L., F. Memmott, and D.G. Liere. 2008 Grafting methods for watermelon production. HortScience 43:1677-1679.

Hassell, R.L. and J. Schultheis. 2002. Seedless watermelon transplant production guide. 20 May 2012. $<$ http://gcrec.ifas.ufl.edu/watermelons/Triploid Production_Guide/Seedless\%20watermelon\% $20 \% 20$ transplant $\% 20$ quide.ppt $>$.

Louws, F.J., C.L. Rivard, and C. Kubota. 2010. Grafting fruiting vegetables to manage soilborne pathogens, foliar pathogens, arthropods and weeds. Sci. Hort. 127:127-146.

Memmott, F.D. 2010. Refinement of innovative watermelon grafting methods with appropriate choice of developmental stage, rootstock genotype, and root treatment to increase grafting success. MS thesis, Clemson Univ., Clemson, SC.

Memmott, F.D. and R.L. Hassell. 2010. Watermelon (Citrullus lanatus) grafting method to reduce labor cost by eliminating rootstock side shoots. Acta Hort. 871:389-394 (abstract).

Ozlem, A., N. Ozdemir, and Y. Gunen. 2007. Effect of grafting on watermelon plant growth, yield, and quality. J. Agron. 6: 362-365.

Rutledge, A.D. 2009. Growing vegetable transplants in Tennessee. The University of Tennessee Agricultural Extension Service [online]. 20 Feb. 2013. <https://utextension.tennessee.edu/ publications/Documents/PB819.pdf $>$.

SAS Institute Inc. 1989-2010. Jump, Version 10. SAS Institute Inc., Cary, NC.

Savvas, D., G. Colla, Y. Rouphael, and D. Schwarz. 2010. Amelioration of heavy metal and nutrient stress in fruit vegetables by grafting. Sci. Hort. 127:156-161 
Sigüenza, C., M. Schochow, T. Turini, and A. Ploeg. 2005. Use of Cucumis metuliferus as a rootstock for melon to manage Meloidogyne incognita. J. Nematol. 37:276-280.

Steffens, G.L. and H.M. Cathey. 1969. Selection of fatty acid derivatives: Surfactant formulations for the control of plant meristems. J. Agr. Food Chem. 17(2):312-317.

Steffens, G.L., T.C. Tso, and D.W. Spaulding. 1967. Fatty alcohol inhibition of tobacco axillary and terminal bud growth. J. Agr. Food Chem. 15:972-975.

Thies, J.A., J.J. Ariss, R.L. Hassell, S. Olson, C.S. Kousik, and A. Levi. 2010. Grafting for management of Southern root-knot nematode, Meloidogyne incognita, in watermelon. Plant Dis. 94:1195-1199.

U.S. Department of Agriculture, National Agricultural Statistics Service. 2012. Crop values 2011 summary. USDA National Agricultural
Statistics Service [online]. 15 Apr. 2012 $<$ http://usda01.library.cornell.edu/usda/current/ CropValuSu/CropValuSu-02-16-2012.pdf>.

U.S.Department of Agriculture, National Agricultural Statistics Service. 2013. Quick stats. 3 Feb. 2013. <http://www.nass.usda.gov>.

Wheeler, J.J., H. Seltmann, and A.G. Motten. 1991. The mode of action of fatty alcohols on leaf tissue. J. Plant Growth Regul. 10:129137 